\title{
Effect of somatostatin on prolactin in rainbow trout (Oncorhynchus mykiss) pituitary cells in primary culture
}

\author{
P. Le Goff*†, C. Weil*, Y. Valotaire $\nmid$, J. F. Gonnard* and P. Prunet* \\ *I.N.R.A., Laboratory of Fish Physiology, Campus de Beaulieu, 35042 Rennes Cédex, France \\ †Laboratory of Molecular Biology, University of Rennes I, Campus de Beaulieu, 35042 Rennes Cédex, \\ France
}

(Requests for offprints should be addressed to P. Prunet)

REVISED MANUSCRIPT RECEIVED 20 March 1992

\begin{abstract}
To study the control of prolactin secretion in fish, an in-vitro technique using a monolayer cell culture system of rainbow trout pituitary glands was developed. Such secretion was characterized by measurement of both prolactin release and prolactin mRNA content using a trout prolactin cDNA as a probe. This cell culture technique, already used to study the regulation of gonadotrophin secretion in rainbow trout, was further validated by measuring total DNA and protein content. Both parameters appeared to be stable after 2 days of culture. Studying the effect of somatostatin (SRIF) on prolactin cells indicated that a maximal inhibitory effect $(62 \%)$ was observed after $24 \mathrm{~h}$ of treatment. Significant inhibition of prolactin release was obtained for SRIF doses ranging from $50 \mathrm{nM}$ to $1 \mu \mathrm{M}$. However, in the same experiment, SRIF was much more potent as an inhibitor of growth hormone release. Short-term $(<12 \mathrm{~h})$ incubation with SRIF did not induce a significant change
\end{abstract}

in prolactin release, whereas growth hormone release was reduced at as early as $1 \mathrm{~h}$ after SRIF exposure. SRIF did not have a significant effect on total prolactin content or prolactin mRNA levels, suggesting the absence of an effect on prolactin synthesis. No increase in the magnitude of the inhibitory effect of SRIF was observed when using pituitary cells from immature, mature male or mature female trout. When comparing effects on primary cultures containing cells from the whole pituitary with a prolactin cell-enriched population, SRIF appeared to have the same inhibitory effect on prolactin release, supporting a direct action of SRIF on prolactin cells. These results provide further support for SRIF being a prolactin-inhibiting factor in rainbow trout and acting as a modulator of a dominant stimulatory control of prolactin release.

Fournal of Molecular Endocrinology (1992) 9, 137-146

\section{INTRODUCTION}

Somatostatin (SRIF), initially characterized in mammals as an inhibitor of growth hormone (GH) secretion, has also been shown to affect prolactin secretion. In-vitro studies indicate that SRIF inhibits stimulated release of prolactin (Vale et al. 1974; Drouin et al. 1976; Enjaibert et al. 1982) and, under discrete endocrine conditions, SRIF has a negative effect on prolactin secretion in vivo (Gooren et al. 1984; Enjalbert et al. 1986; Karashima \& Schally, 1987). In teleost fish, the involvement of SRIF in the control of prolactin release from adenohypophysial cells has also been suggested. Using immunocytochemical techniques, the presence of SRIF-like material in the brain of several fish species has been reported; immunoreactivity is localized both in the hypothalamus and in the neurohypo- physis close to the adenohypophysis (Dubois et al. 1979; Kah et al. 1982; Vigh-Teichmann et al. 1983; Batten \& Wigham, 1984; Olivereau et al. 1984; Grau et al. 1985; Marchant et al. 1989). Moreover, in-vitro inhibition of basal prolactin release from incubated pituitary fragments has been reported in two teleost fish species, Poecilia and Tilapia; both physiological and cytochemical studies support a role for SRIF as a predominant inhibitory factor of prolactin secretion (Grau et al. 1982; Batten \& Wigham, 1984; Wigham \& Batten, 1984; Grau et al. 1985, 1987).

In rainbow trout (Oncorhynchus mykiss), studies using incubations of whole pituitary gland have led to contradictory results (James \& Wigham, 1984; Johnston \& Wigham, 1990). However, in these studies, measurements of prolactin levels were performed using partially validated electrophoretic techniques and, therefore, the results should be 
interpreted with caution. The present study was undertaken to evaluate the response of prolactin cells to SRIF in rainbow trout. In teleost fish, pituitary structure is characterized by the presence of hypothalamic fibres terminating in the proximity of adenohypophysial cells. In order to study direct effects of SRIF on prolactin cells, and to preclude the possibility of interference from endogenous neuromediators released from nerve endings, primary cultures of rainbow trout pituitary cells (Weil et al. 1986) were used in the present study.

\section{MATERIALS AND METHODS}

\section{Animals}

Unless indicated otherwise, pituitaries were collected from immature rainbow trout (Oncorhynchus mykiss) of both sexes. Fish were purchased from a freshwater hatchery and kept in recirculating water at a constant temperature $\left(13^{\circ} \mathrm{C}\right)$ and with natural photoperiod. Adult rainbow trout $(600 \mathrm{~g})$ were mature male and female fish from a summerspawning strain used 2 months before spawning and spermiation.

\section{Cell processing}

Whole pituitary glands or rostral pars distalis (RPD) fragments dissected under the microscope were obtained immediately following decapitation. Cells were obtained as previously described for whole pituitary by Weil et al. (1986). For certain experiments (indicated in the text), culture plates were treated with a solution of poly-L-lysine $\left(5 \mu \mathrm{g} / \mathrm{cm}^{2}\right.$; Sigma Chemical Co., St Louis, MO, U.S.A.) before cell plating. Following dispersion, cells were washed twice with culture medium: RPMI medium (GIBCO/BRL, Cergy-Pontoise, France) supplemented with Hepes $(20 \mathrm{~mm}), \mathrm{NaHCO}_{3}$ $(9 \mathrm{mM}), 100 \mathrm{U}$ penicillin $/ \mathrm{ml}, 0.25 \mu \mathrm{g}$ Fongizone $/ \mathrm{ml}$ (GIBCO) and $2 \%$ serum substitute (Ultroser SF; IBF, Villeneuve-la-Garenne, France). The cells were placed in 24 -well culture plates $\left(2 \times 10^{5}\right.$ cells in $1 \mathrm{ml}$ per well; Nunc, Kamstrup, France) or in 96well culture plates $\left(5 \times 10^{4}\right.$ cells in $250 \mu \mathrm{l}$ per well; Nunc). Plates were maintained at $18^{\circ} \mathrm{C}$ for the entire culture period.

\section{Validation of culture technique}

\section{DNA and protein measurements}

Intracellular DNA and protein contents were measured over 8 days of culture by collecting cultured pituitary cells every 2 days. Recovery of intracellular material was performed after proteinase $\mathrm{K}$ treatment (Vassef, 1987) and sonication. DNA and protein levels were determined by fluorescence measurement using the Hoechst reagent (Labarca \& Paigen, 1980) and by colour absorption using the Bradford technique (Bradford, 1976) respectively.

\section{Prolactin and actin $m R N A$ measurement}

Both mRNAs were measured using cytoplasmic slot blots prepared according to White et al. (1986). Cells were collected after proteinase $\mathrm{K}$ treatment (Vassef, 1987 ) and the hybridization procedure was performed according to Thomas (1980). The probes used in these hybridization experiments were the EcoRI-EcoRI restriction fragment of the trout prolactin cDNA (Mercier et al. 1989) and the EcoRIEcoRI restriction fragment of actin (Pakdel et al. 1989 ). Both cDNAs were labelled using the randomprimer technique with $5^{\prime}\left[\alpha_{-}{ }^{32} \mathrm{P}\right] \mathrm{dC}$ TP $\quad(800 \mathrm{Ci} /$ mmol; Amersham, Les Ulis, France). In order to confirm specificity of the hybridization, separate control experiments were performed; cytoplasm from trout hepatocytes or from pituitary digested with RNAse A was hybridized with prolactin probe under the same conditions.

Immunocytochemical staining of cultured cells The immunocytochemical staining of prolactin cells was performed on dispersed cells fixed in picric acid formaldehyde solution using the peroxidase procedure previously described (Weil et al. 1992). The rabbit antiserum used for prolactin cells was raised against chinook salmon prolactin at $1 / 1000$ dilution (Prunet et al. 1985). Percentages of prolactin cells among total pituitary cells or RPD cells were determined by counting stained cells; each percentage was the result of three independent analyses and a mean of about 1000 cells was counted in each population.

\section{Effect of SRIF on prolactin secretion}

After 2, 3, 4, 5 or 6 days of cell culture, the media were removed and the attached cells were washed twice with culture medium without Ultroser. Subsequently, $250 \mu \mathrm{l}$ medium with or without neuropeptide were added to each well. Following exposure to the neuropeptide, the media were collected after centrifugation and stored at $-20^{\circ} \mathrm{C}$ until assayed. Intracellular content of prolactin was also determined in some experiments. After removal of the medium, culture plates were washed twice with phosphate saline buffer and subsequently incubated with radioimmunoassay buffer containing $0.1 \%$ Triton X-100 (Serva, Heidelberg, Germany) for $6 \mathrm{~h}$ at $18{ }^{\circ} \mathrm{C}$ until complete breakdown of the cells had occurred. The resulting cell lysates were stored at 
$-20^{\circ} \mathrm{C}$ until assayed. Prolactin and $\mathrm{GH}$ were measured in duplicate using specific radioimmunoassays, as previously described by Prunet et al. (1985) and Le Bail et al. (1991) respectively.

\section{Reagents}

Synthetic SRIF (somatostatin 14) was kindly provided by Sanofi (Montpellier, France); Sandostatin (SMS 201-995) was generously donated by Sandoz Laboratories (Rueil-Malmaison, France).

\section{Statistical analysis}

The data were subjected to the Mann-Witney nonparametric test for the comparison of differences between group means. Differences between groups were considered significant if $P<0.05$.

\section{RESULTS}

\section{Validation of the cell culture technique for prolactin secretion studies}

As previously described by Weil et al. (1986), after collagenase treatment, rainbow trout pituitary glands yielded dispersed cells of high viability (an average of $85 \%$ by trypan blue exclusion test). Measurement of total DNA and protein in cultured pituitary cells indicated a $50 \%$ decrease in both parameters between freshly dissociated cells (day 0) and cells after 2 days of culture and later (Fig. $1 a$ and $b$ ). Such a decrease was probably due to material (dead cells or cell fragments) eliminated when the cells were washed after plating. Measurement of prolactin and actin mRNA in pituitary cultured cells was also performed. Prolactin and actin mRNA decreased to $40 \%$ and $78 \%$ respectively after 2 days of culture. However, on day 4, both mRNAs increased to reach levels close to initial values and stayed stable until day 8 (Fig. $2 a$ and $b$; Fig. $1 a$ and $b$ ). Effects of pretreatment of the culture plate with poly-L-lysine, a factor shown to improve cell adhesion, were also investigated. In the presence of polyL-lysine, a slight but significant $(P<0.05)$ increase $(17 \%)$ in the number of attached cells was observed, as indicated by total DNA measurement (after 3 days of culture, $3 \cdot 55 \pm 0.31 \mu \mathrm{g}$ DNA/well with poly-L-lysine; $2.95 \pm 0.9 \mu \mathrm{g} \mathrm{DNA} /$ well in the control plate).

\section{Effects of SRIF on prolactin and GH secretion}

The basal secretion rate of prolactin increased progressively with increasing time of culture. After 12,
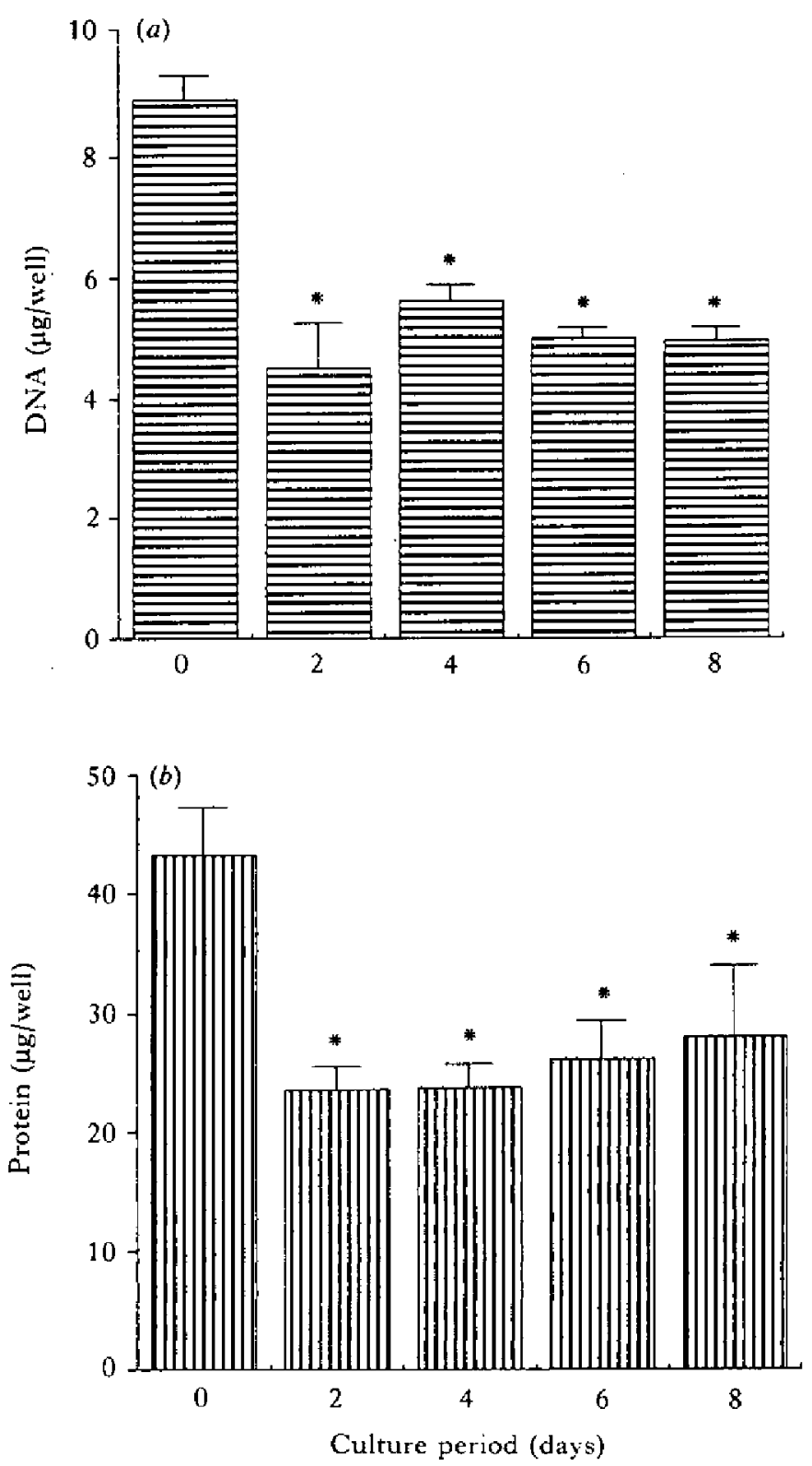

FIGURE 1. (a) DNA and (b) protein levels in pituitary cells in primary culture after different periods; $2 \times 10^{5}$ cells were initially plated. The cells were cultivated with Ultroser SF (2\%) and the medium was renewed every 2 days. DNA was measured by the fluorimetric technique using the Hoechst reagent. Protein was measured by the Bradford technique. Values are means \pm S.D. $(n=8)$.

* $P<0.05$ compared with day 0 .

24,30 and $48 \mathrm{~h}$ of exposure to $1 \mu \mathrm{M}$ SRIF, a significant decrease in prolactin release was observed (Fig. $3)$. When prolactin data were expressed as percentages of the control values, the inhibitory effect of SRIF at $12 \mathrm{~h}$ and later was rather constant, from 54 to $62 \%$, with a maximal effect at $24 \mathrm{~h}$ of treatment. Similar inhibitory effects were also observed when using pituitary cells collected from male or female mature fish (data not shown). When cultured cells were subjected to poly-L-lysine pretreatment, one 

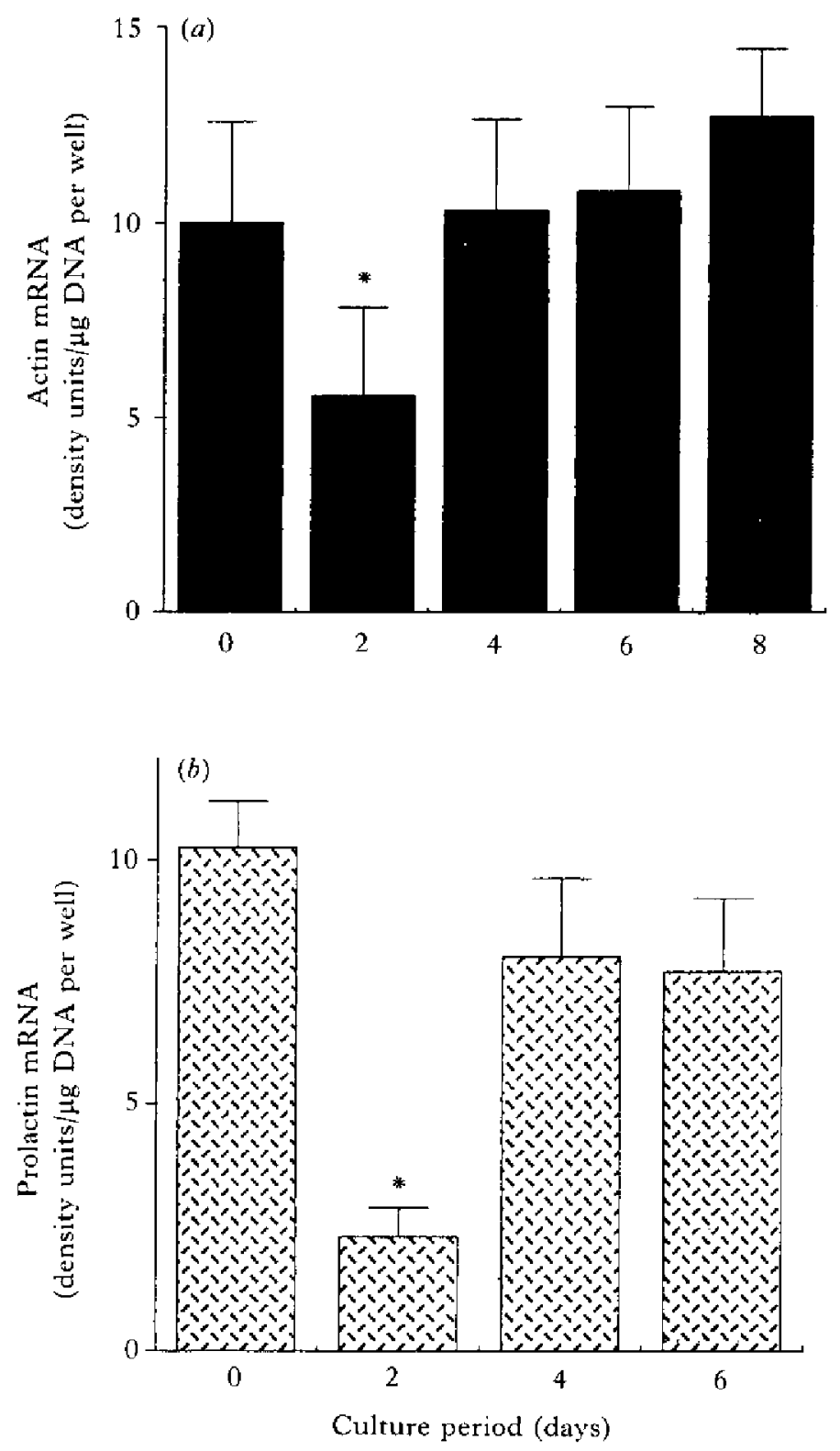

FIGURE 2. (a) Actin and (b) prolactin mRNA levels in pituitary cells in primary culture at different times; $2 \times 10^{5}$ cells were initially plated. The cells were cultivated with Lltroser SF $(2 \%)$ and the medium was renewed every 2 days. Prolactin and actin $m$ RNAs were measured by cytoplasmic slot-blot hybridization. The arbitrary density units were divided by the quantity of DNA per well. Values are means \pm S.D. $(n=6) . * P<0.05$ compared with day 0 .

dose $(1 \mu \mathrm{M})$ of SRIF for $24 \mathrm{~h}$ induced a slightly higher inhibitory effect when compared with cells not pretreated $(67 \cdot 1 \pm 2 \cdot 25 \%$ without poly-L-lysine; $77 \cdot 4 \pm 8 \cdot 9 \%$ with poly-L-lysine).

When cells were exposed to $1 \mu \mathrm{M}$ SRIF for a shorter period than $12 \mathrm{~h}$, no significant effect on prolactin release was observed (Table 1 ). In contrast, $\mathrm{GH}$ release, measured in the same experiment, was significantly reduced from as early as $1 \mathrm{~h}$ after drug exposure (Table 1). The testing of different concentrations indicated that SRIF was effective in inhibiting basal prolactin release in a dose-dependent manner, $50 \mathrm{~nm}$ being the lowest effective dose (Fig. 4). When tested on $\mathrm{GH}$ release in similar conditions, SRIF appeared to be much more potent as an inhibitory factor; doses as low as $100 \mathrm{pm}$ had a suppressive effect on GH release (Fig, 5). The specificity of these effects was tested using a SRIF analogue, SMS 201-995. Whereas SMS 201-995 had no effect on prolactin release, it inhibited $\mathrm{GH}$ release in a dose-dependent manner; however, SMS 201-995 appeared to be about ten times less potent than SRIF when tested in the same experiment (Fig. 5).

Effects of SRIF on prolactin synthesis were also analysed. SRIF had no effect on total prolactin content (the sum of prolactin released and intracellular prolactin; Fig. $3 b$ ). Moreover, application of $1 \mu \mathrm{M}$ SRIF for $96 \mathrm{~h}$ did not change prolactin mRNA levels, whereas such treatment significantly reduced prolactin release (Fig. 6).

\section{Effects of enrichment on the response of prolactin cells to SRIF}

Primary cultured cells were prepared from the rostral part of the adenohypophysis, which contains all prolactin cells; this led to a significant enrichment of the culture with prolactin cells, as measured by immunocytochemistry (60\% prolactin cells in RPD fragments compared with $20 \%$ for the whole pituitary). Exposure of RPD cells to $1 \mu \mathrm{M}$ SRIF for $30 \mathrm{~h}$ induced a significant $(P<0.05)$ decrease in prolactin release, similar to that obtained when using the whole pituitary gland $(58 \cdot 8 \pm 17 \%$ and $48 \cdot 8 \pm 6 \%$ respectively, established from four different experiments).

\section{DISCUSSION}

The development of a primary culture technique for trout pituitary cells, associated with the measurement of prolactin levels with a specific radioimmunoassay for salmonid prolactin (Prunet et al. 1985), appears to provide a suitable new tool for studying the direct control of prolactin secretion. Several parameters were measured in this study, validating this primary culture system, previously developed for the study of gonadotrophin secretion (Weil et al. 1986). Thus, stable values for total DNA and protein content after 2 days indicate that cells were attached. These results also suggest the absence of cell division in our primary culture; such an absence of fibroblast proliferation has already been described by Weil et al. (1986). This is different to that described in 


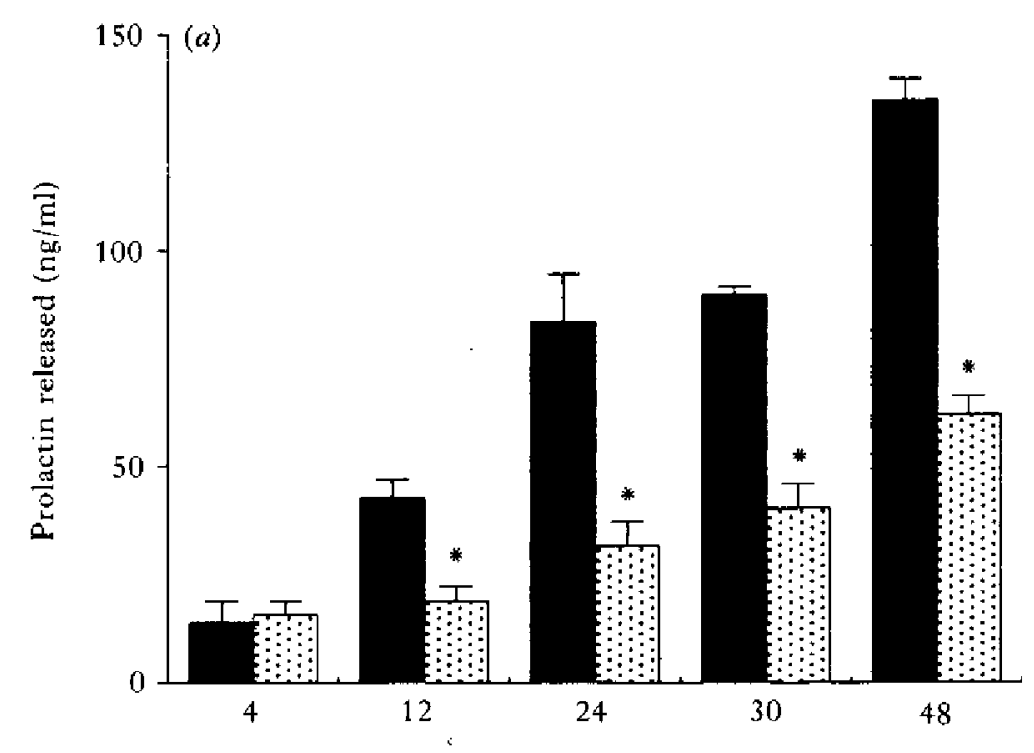

(b)

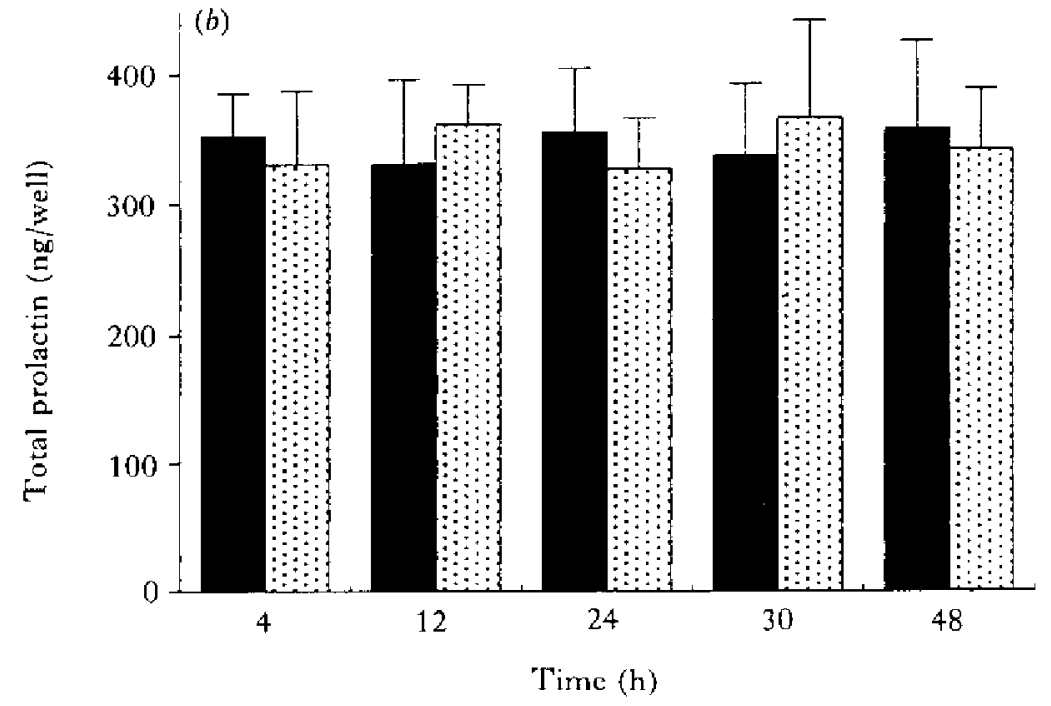

FIGURE 3. Time-course of prolactin release and total prolactin of control (solid bars) and somatostatin (SRIF)-stimulated cells (stippled bars). (a) Prolactin released into the culture medium; (b) total prolactin; $2 \times 10^{5}$ cells were initially plated. The cells were treated with SRIF $(1 \mu \mathrm{M}) 3$ days after plating. Values are means \pm S.D. $(n=6)$. * $P<0.05$ compared with controls.

TABLE 1. Effect of one dose of somatostatin (SRIF; $1 \mu \mathrm{M}$ ) on prolactin and GH release from cultured pituitary cells after different incubation periods. Each value represents the mean \pm S.E.M. The number of replicates are given in parentheses

\begin{tabular}{|c|c|c|c|c|}
\hline \multirow{3}{*}{$\begin{array}{l}\text { Incubation }(\mathrm{h}) \\
1\end{array}$} & \multicolumn{2}{|c|}{ Prolactin release $(\mathrm{ng} / \mathrm{ml})$} & \multicolumn{2}{|c|}{ GH release $(\mathrm{ng} / \mathrm{ml})$} \\
\hline & Control & SRIF & Control & SRIF \\
\hline & $\begin{array}{c}3.07 \pm 0.68 \\
(4)\end{array}$ & $\begin{array}{c}2 \cdot 02 \pm 0 \cdot 19 \\
(4)\end{array}$ & $\begin{array}{c}3 \cdot 20=0 \cdot 45 \\
(5)\end{array}$ & $\begin{array}{c}1.08 \pm 0 \cdot 25 * \\
(5)\end{array}$ \\
\hline 6 & $\begin{array}{c}2.88 \pm 0.71 \\
(4)\end{array}$ & $\begin{array}{c}2 \cdot 73 \pm 0 \cdot 44 \\
(5)\end{array}$ & $\begin{array}{c}4 \cdot 49=0 \cdot 61 \\
(5)\end{array}$ & $\begin{array}{c}1 \cdot 62 \pm 0 \cdot 22^{* * *} \\
\text { (5) }\end{array}$ \\
\hline 24 & $\begin{array}{c}10 \cdot 07 \pm 0 \cdot 46 \\
(5)\end{array}$ & $\begin{array}{c}3 \cdot 43 \pm 0 \cdot 90^{* *} \\
(4)\end{array}$ & $\begin{array}{c}62 \cdot 90 \pm 5 \cdot 16 \\
\text { (5) }\end{array}$ & $\begin{array}{c}1 \cdot 79 \pm 0 \cdot 25^{* * *} \\
(5)\end{array}$ \\
\hline
\end{tabular}

${ }^{*} P<0.05,{ }^{*} P<0 \cdot 01$, values significantly different from corresponding controls. 


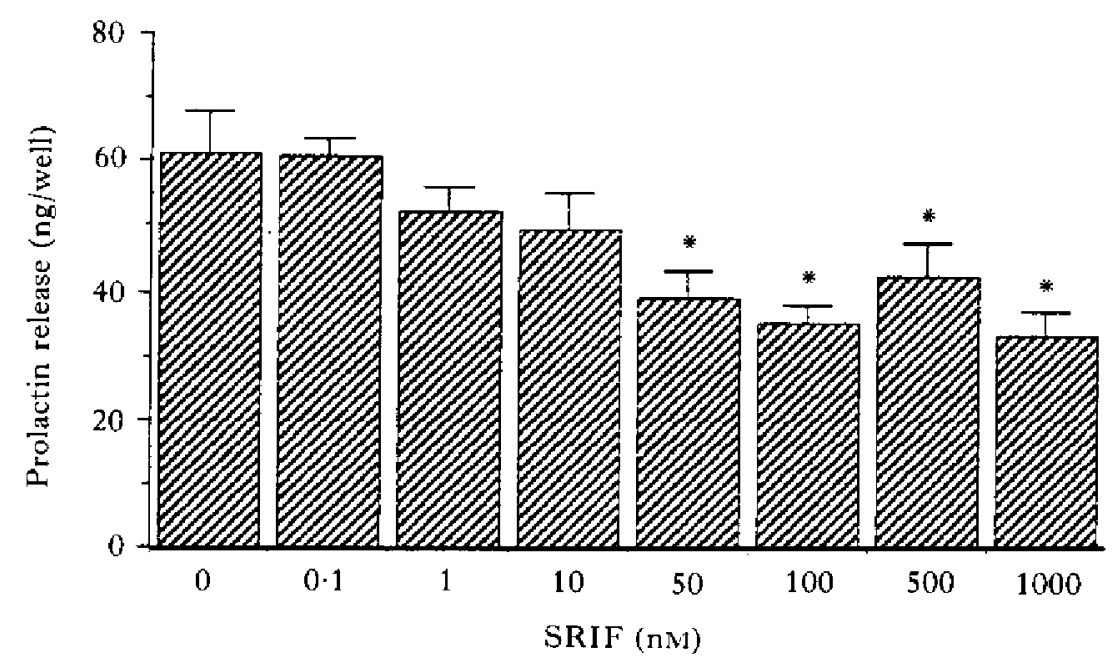

FIGURE 4. Prolactin release from pituitary cells in primary culture after treatment with various concentrations of somatostatin (SRIF); $2 \times 10^{5}$ cells were initially plated. The treatment was performed 3 days after plating, for $48 \mathrm{~h}$. Values are means \pm s. . $(n=4)$.

*P<0.05 compared with controls.

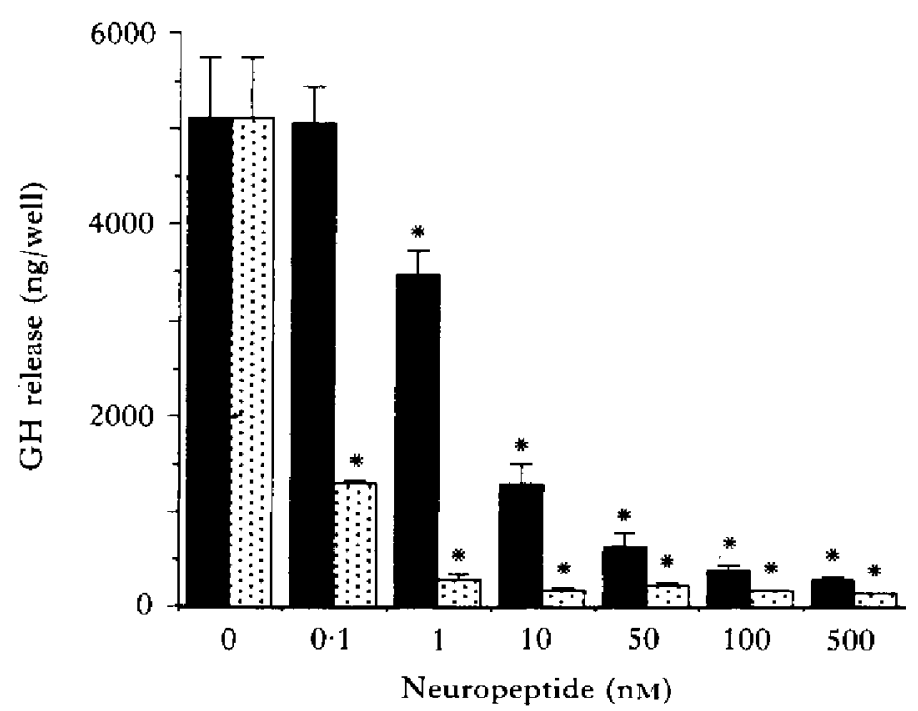

FIGURE 5. GH release after treatment with various concentrations of somatostatin (SRIF; stippled bars) and SRIF analogue (SMS 201-995; solid bars) by pituitary cells in primary culture; $5 \times 10^{4}$ cells were initially plated. The treatment was performed 3 days after plating, for $48 \mathrm{~h}$. Culture media collected at the end of the experiment were stored at $-20^{\circ} \mathrm{C}$, diluted $1 / 2$ in radioimmunoassay buffer containing $1 \%$ bovine serum albumin. Values are means \pm S.D. $(n=5)$. ${ }^{*} P<0.01$ compared with controls.

mammals, where cell division, often associated with fibroblast invasion, has been reported in rat pituitary primary culture (Steinberger et al. 1973; O'Conner et al. 1980).

Measurements of prolactin and actin mRNA indicated an effect of culture duration; after 2 days of culture, a significant drop in the levels of both mRNAs was observed, which may be due to a decrease in gene expression. However, after 4 days of culture, mRNA levels increased to stabilize. A similar observation was made by Clayton \& Darnell (1983) with hepatocytes in primary culture; whereas actin and tubulin mRNA stayed stable during culture, levels of several other mRNAs coding for proteins specific to liver function appeared to decrease during the first days of culture. In our study, prolactin mRNA increased after 2 days and reached values close to those measured in freshly dissociated cells. This suggests that prolactin cells stayed at a differentiated stage during our experiments. However, mRNA levels measured in freshly dissociated cells are not necessarily equal to those which can be measured in vivo, as modifications of gene expression probably occur during the dissociation period, which lasts $20 \mathrm{~h}$ in our protocol.

The analysis of mRNA levels, suggesting a necessary preincubation period to allow cells to recover, is further supported by the study of prolactin release from control and SRIF-treated cells after different preincubation periods. Our results (data not shown) clearly indicate that maximum inhibition is observed after 3 or 4 days of preincubation. Longer durations lead to lower basal prolactin release and to lower responses to SRIF treatment. The use of an attachment factor, poly-L-lysine, led to an increase in prolactin cell sensitivity to SRIF. Similar stimulation of cellular responses by polymers which interact with components of the cell surface have been observed previously; gonadotrophin release by cultured rat 

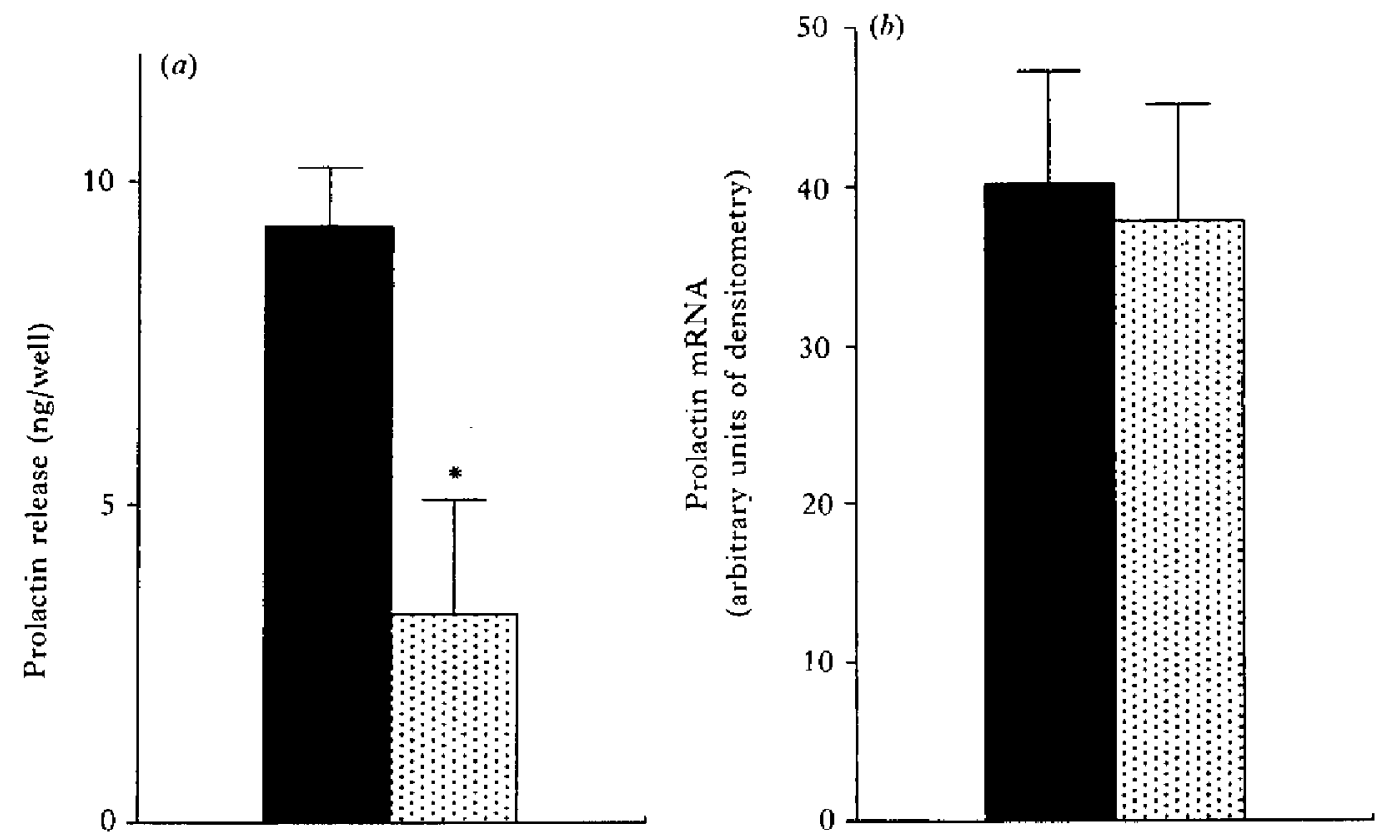

FIGURE 6. Somatostatin (SRIF) action on (a) prolactin release by pituitary cells and $(b)$ the prolactin mRNA content of these cells. Controls are represented by solid bars, SRIF-treated cells by stippled bars; $5 \times 10^{4}$ cells were initially plated on a support pretreated with poly-I,-lysine. Cells were treated with SRIF (1 $\mu \mathrm{M}) 2$ days after plating, for $96 \mathrm{~h}$. Culture medium was renewed $48 \mathrm{~h}$ after initiation of the treatment. Prolactin mRNA was measured by cytoplasmic slot-blot hybridization. Values are means \pm S.D. $(n=6) . * P<0 \cdot 05$ compared with control.

pituitary cells appears to be stimulated after polyL-lysine treatment, presumably through interactions between the charged polymer and gonadotrophinreleasing hormone receptor (Conn et al. 1984).

The use of such a primary culture system allows us to show an inhibitory, dose-related effect of SRIF on prolactin release. With the lack of nerve terminal and synaptic vesicles in our culture system, one could assume that the inhibition of prolactin release was the result of a direct action of SRIF on prolactin cells. This is further supported by the study of the effects of SRIF on prolactin cell-enriched preparations, obtained by culturing RPD pituitary fragments. A three-times enrichment led to the same inhibitory effect of SRIF $(1 \mu \mathrm{M})$ as was observed when using whole pituitary gland. This result supports the absence of an indirect effect via another pituitary cell type.

Measurements of total prolactin content and prolactin mRNA content in SRIF-treated primary cultures indicate the absence of an effect of SRIF on prolactin synthesis in rainbow trout. Studies of the effects of SRIF on prolactin cells in another fish species, Poecilia latipinna, by quantitative electron microscopy indicated that prolactin synthesis might be affected during in-vitro incubation of pituitary glands in the presence of SRIF (Batten \& Wigham, 1984). However, such an effect was not observed when prolactin synthesis was quantified by electrophoresis (Wigham \& Batten, 1984). In Tilapia mossambica, Wigham et al. (1977) and Rivas et al. (1986) did not find a consistent effect of SRIF on prolactin synthesis. This also agrees with the mode of action of this neuropeptide on GH cells in mammals; SRIF did not modify the transcriptional activity of the $\mathrm{GH}$ gene and had its primary effect at the level of hormone release (Barinaga et al. 1985; Morel et al. 1989).

The dose-related activity of SRIF on prolactin release appears to range from $50 \mathrm{nM}$ to $1 \mu \mathrm{M}$, the maximal activity being observed at $100 \mathrm{~nm}$. This is a similar range of activity to that reported in another fish species, Tilapia mossambica, using incubated pituitary fragments (Grau et al. 1982; Rivas et al. 1986). However, in our study, SRIF appears to have a much more potent effect on $\mathrm{GH}$ release, as a maximal inhibitory effect ( $95 \%$ inhibition) was observed when using as low a concentration as $1 \mathrm{nM}$. This is in agreement with previous in-vitro studies of the SRIF inhibition of GH release from rainbow trout pituitary cultured cells (Luo et al. 1990; Perez Sanchez et al. 1992). Interestingly, such a strong inhibition of hormone release by SRIF was also observed with prolactin release when using cultured pituitary cells collected from oestradiol-treated rats (Kimura et al. 1986). These authors concluded that 
oestradiol acts on mammotrophs probably by increasing the number of SRIF receptors at the pituitary level. In rainbow trout, several arguments suggest the absence of such a regulation. First, in our study, SRIF had similar effects on prolactin released from cultured cells obtained from immature, mature male and mature female rainbow trout; secondly, invivo oestradiol treatment of rainbow trout did not increase the sensitivity of cultured prolactin cells to SRIF (P. Prunet, unpublished data) and thirdly, localization of oestradiol receptor mRNA in rainbow trout pituitary gland using in-situ hybridization indicates the absence of oestrogen receptor synthesis in prolactin cells (Le Goff et al. 1992).

In order to test the specificity of the inhibitory effect of SRIF on prolactin release, a long-acting SRIF analogue was incubated in our pituitary cell culture system. When tested at doses ranging from $0 \cdot 1 \mathrm{nM}$ to $1 \mu \mathrm{M}$, this analogue appeared to be ineffective regarding prolactin release. This is not surprising as i) SMS 201-995 appeared to be about 100 times less potent than SRIF when tested in the same experiment on $\mathrm{GH}$ release (Fig. 5) and ii) the lowest effective dose of SRIF inhibiting prolactin release was shown to be $50 \mathrm{nM}$.

A time-course study of the response of prolactin cells to SRIF showed that short-term incubation $(<12 \mathrm{~h})$ does not lead to significant changes in hormone release (Table 1 and Fig. 3). Such a situation appears to be specific to prolactin and cannot be explained by a particular mechanism of action for SRIF on trout pituitary cells or by a partial degradation of SRIF during incubation. Indeed, measurement of GH levels in the same culture experiment indicated that SRIF significantly inhibits $\mathrm{GH}$ release after short-term exposure and is still fully active after $48 \mathrm{~h}$ of incubation. Such a delay in the response of trout prolactin cells may be associated with the particular behaviour of these cultured cells; effectively, prolactin levels in control wells appeared to be rather constant during the first $8 \mathrm{~h}$ after cell washing and increased significantly only at $12 \mathrm{~h}$. Moreover, SRIF inhibited prolactin release only after $12 \mathrm{~h}$, when a significant increase in basal hormone release was observed. This suggests that, after an initial quick burst of hormone due to cell washing, prolactin released from cultured cells is low. Conversely, basal $\mathrm{GH}$ release increased steadily from $1 \mathrm{~h}$ until $24 \mathrm{~h}$ (Table 1 and Perez Sanchez et al. 1992), suggesting a high secretion rate for this hormone from trout pituitary cells in culture. This is in agreement with a study on prolactin and $\mathrm{GH}$ release from the pituitary of rainbow trout in culture (Yada $e t$ al. 1991). These authors concluded a dominant stimulatory control of rainbow trout prolactin cells by the hypothalamus, as suggested by Gonnet et al. (1989), and a dominant inhibitory control for GH cells. Such particular dominant controls of prolactin and GH secretion in rainbow trout, the converse of those described in mammals, are reflected in the present time-course study of the effects of SRIF on prolactin and $\mathrm{GH}$ release from trout pituitary cells in culture.

In conclusion, our study demonstrates that SRIF has direct inhibitory effects at physiological doses on cultured prolactin cells. This supports a role for SRIF as a potential prolactin-inhibiting factor in rainbow trout. The observation of such inhibitory effects only when the secretion rate of prolactin is increasing also suggests that SRIF acts as a modulator of a dominant stimulatory control by other hypothalamic factors. Such interactions have already been shown in the rat, where in-vitro vasoactive intestinal peptide or thyrotrophin-releasing hormone stimulation of prolactin release was prevented by SRIF (Enjalbert et al. 1982). The characterization of hypothalamic prolactin-releasing factors in rainbow trout and their interaction with SRIF are presently under investigation in our laboratory.

\section{ACKNOWLEDGEMENTS}

We are indebted to Dr H. Vaudry, GREM, University of Rouen, for his suggestions and critical comments on the manuscript. We thank Dr P. Y. Le Bail for supplying $\mathrm{GH}$ radioimmunoassay products. SMS 201-995 was kindly provided by Sandoz Laboratories and synthetic SRIF (somatostatin 14) was generously provided by Sanofi. The authors also express their gratitude to J. Sorais for typing this manuscript. This study was supported in part by a grant from region Bretagne (BRITTA programme) to INRA.

\section{REFERENCES}

Barinaga, M., Bilezikjan, L. M., Vale, W. E., Rosenfeld, M. G. \& Evans, R. M. (1985). Independent effects of growth hormone releasing factor on growth hormone release and gene transcription. Nature 314, 279-281.

Batten, T. F. C. \& Wigham, T. (1984). Effects of TRH and somatostatin on releases of prolactin and growth hormone in vitro by the pituitary of Poecilia latipinna. Cell and Tissue Research 237, 595-603.

Bradford, M. M. (1976). A rapid and sensitive method for the quantification of microgram quantities of protein utilizing the principle of protein dye binding. Analytical Biochemistry 72, 248-254.

Clayton, D. F. \& Darnell, J. E., Jr. (1983). Changes in liverspecific compared to common gene transcription during primary culture of mouse hepatocytes. Molecular and Cellular Biology 3, 1552-1561.

Conn, P. M., Rogers, D. C., Seay, R. S. \& Staley, D. (1984). Activation of luteinizing hormone release from pituitary cells by polycations. Endocrinology 115, 1913-1917. 
Drouin, J., De Lean, A., Rainville, D, Lachance, R. \& Labrie, F. (1976). Chatacteristics of the interaction between thyrotropin releasing hormone and somatostatin for thyrotropin and prolactin release. Endocrinology 98, 514-521.

Dubois, M. P., Billard, R., Breton, B. \& Peter, R. E. (1979). Comparative distribution of somatostatin, LHRH, neurophysin and $\alpha$-endorphin, in the rainbow trout: an immunocytological study. General and Comparative Endocrinology 37, 220-232.

Enjalbert, A., Bertrand, P., Le Dafniet, M., Epelbaum, J., Hugues, J. N., Kordon, C., Myse, E., Peillon, F. \& Shu, C. (1986). Somatotastin and regulation of prolactin secretion. Psychoneuroendocrinology 11, 155-165.

Enjalbert, A., Epelbaum, J., Arancibia, S., Tapia-Arancibia, I., Bluet-Pajot, M. T. \& Kordon, C. (1982). Reciprocal interactions of somatostatin with thyrotropin-releasing hormone and vasoactive intestinal polypeptide on prolactin and growth hormone secretion in vitro. Endocrinology 111, $42-47$.

Gonnet, F., Prunet, P., Barret, A. \& Grousselle, P. (1989). Hypothalamic control of prolactin release in the rainbow trout Salmo gairdneri: in vitro studies. Fish Physiology and Biochemistry 7, 307-308.

Gooren, L. J. G., Harmen-Louman, W. \& Van Kessel, H. (1984). Somatostatin inhibits prolactin release from the lactotroph primed with oestrogen and cyproterone acetate in man. Fournal of Endocrinology 103, 333-335.

Grau, E. G., Ford, C. A., Helms, L. M. H., Shimoda, S. K. \& Cooke, I. M. (1987). Somatostatin and altered medium osmotic pressure elicit rapid changes in prolactin release from the rostral pars distalis of the tilapia Oreochromis mossambicus, in vitro. General and Comparative Endocrinology $65,12-18$.

Grau, E. G., Nishioka, R. S. \& Bern, H. A. (1982). Effects of somatostatin and urotensin II on tilapia pituitary prolactin release and interactions between somatostatin, osmotic presure, $\mathrm{Ca}^{++}$and adenosine $3^{\prime}, 5^{\prime}$-monophosphate in prolactin release in vitro. Endocrinology 110, 910-915.

Grau, E. G., Nishioka, R. S., Young, G. \& Bern, H. A. (1985). Somatostatin-like immunoreactivity in the pituitary and brain of three teleost fish species: somatostatin as a potential regulator of prolactin cell function. General and Comparative Endocrinology 59, 350-357.

James, V. A. \& Wigham, 'T. (1984). Evidence for dopaminergic and serotonergic regulation of prolactin cell activity in the trout Salmo gairdneri. General and Comparative Endocrinology 56, 231-239.

Johnston, L. R. \& Wigham, T. (1990). The effects of ions and hypothalamic factors on the in vitro activity of rainbow trout prolactin cells. General and Comparative Endocrinology 79, 253-260.

Kah, O., Chambolle, P., Dubourg, P. \& Dubois, M. P. (1982). Localisation immunocytochimique de la somatostatine dans le cerveau antérieur et l'hypophyse de deux téléostéens, le cyprin (Carassius auratus) et Gambusia sp. Compte Rendus de l'Académie des Sciences 294, 519-524.

Karashima, T'. \& Schally, A. V. (1987). Inhibitory effects of somatostatin analogs on prolactin secretion in rats pretreated with estrogen or haloperidol. Proceedings of the Society for Experimental Biology and Medicine 185, 69-75.

Kimura, N., Hayafuji, C., Konagaya, H. \& Takahashi, K. (1986). 17 $\beta$-oestradiol induces somatostatin inhibition of prolactin release and regulates SRIF receptors in rat anterior pituitary cells. Endocrinology 119, $1028-1036$.

Labarca, C. \& Paigen, K. (1980). A simple rapid and sensitive DNA assay procedure. Analytical Biochemistry 102, 344-352.
Le Bail, P. Y., Sumpter, J. P., Carracher, J., Mourot, B., Niu, P. D. \& Weil, C. (1991). Development and validation of highly sensitive radioimmunoassay to chinook salmon (Oncorhynchus tschawytscha) growth hormone. General and Comparative Endocrinology 83, 75-85.

Le Goff, P., Salbert, G., Saligaud, C., Prunet, P. \& Valotaire, $Y$. (1992). Absence of prolactin cells response to $17 \beta$-oestradiol treatment in rainbow trout (Oncorhynchus mykiss). Molecular and Cellular Endocrinology. (Submitted.)

Luo, D., Mc Keown, B. A., Rivier, J. \& Wale, W. (1990). In vitro responses of rainbow trout (Oncorhynchus mykiss) somatotrophs to carp growth hormone-releasing factor (GRF) and somatostatin. General and Comparative Endocrinology 80, 288-298.

Marchant, T. A., Fraser, R. A., Andrews, P. C. \& Peter, R. E. (1989). The influence of mammalian and teleost somatostatins on the secretion of growth hormone from goldfish (Carassius auratus L.) pituitary fragments in vitro. Regulatory Peptides 17, 41-52.

Merciet, L., Rentier-Delrue, F., Swemen, D., Lion, M., Le Goff, P., Prunet, P. \& Martial, J. A. (1989). Rainbow trout prolactin cDNA cloning in Escherichia coli. DNA 8 , 119-125.

Morel, G., Dihl, F. \& Gossard, F. (1989). Ultrastructural distribution of growth hormone (GH) mRNA and $\mathrm{GH}$ intron I sequences in rat pituitary gland: effects of $\mathrm{GH}$ releasing factor and somatostatin. Molecular and Cellular Endocrinology 65, 81-90.

O'Conner, J. L., Allen, M. B. \& Malesh, V. B. (1980), Castration effects of the response of rat pituitary cells to luteinizing hormone-releasing hormone: retention in dispersed cell culture. Endocrinology 106, 1706-1714.

Olivereau, M., Ollevier, F., Vandesande, F. \& Olivereau, J. (1984). Somatostatin in the brain and the pituitary of some teleosts. Immunocytochemical identification and the effect of starvation. Cell and Tissue Research 238, 289-296.

Pakdel, F., Le Guellec, C., Vaillant, C., Leroux, M. G. \& Valotaire, $Y$, (1989). Identification and estrogen induction of two estrogen receptor (ER) messenger ribonucleic acids in the rainbow trout liver: sequence homology with other ERs. Molecular Endocrinology 3, 44-51.

Perez Sanchez, J., Weil, C. \& Le Bail, P. Y. (1992). Effects of a human insulin-growth factor -1 on the release of growth hormone by rainbow trout (Oncorhynchus mykiss) pituitary cells. Fournal of Experimental Zoology. (In Press.)

Prunet, P., Boeuf, G. \& Houdebine, L. M. (1985). Plasma pituitary prolactin levels in rainbow trout during adaptation to different salinities. Fournal of Experimental Zoology 235, $187-196$.

Rivas, R. J., Nishioka, R. S. \& Bern, H. A. (1986). In vitro effects of somatostatin and urotensin on prolactin and growth hormone secretion in tilapia, Oreochromis mossambicus. General and Comparative Endocrinology 63, $245-251$.

Steinberger, A., Lhowdhury, M. \& Steinberger, E. (1973). Effect of repeated replenishment of hypothalamic extract on LH and FSH secretion in monolayer cultures of rat anterior pituitary cells. Endocrinology 92, 12-17.

Thomas, P. S. (1980). Hybridization of denatured RNA and small DNA fragments transferred to nitrocellulose. Proceedings of the National Academy of Sciences of the U.S.A. 77, 5201-5205.

Vale, W., Rivier, C., Brazeau, P. \& Guillemin, R. (1974). Effects of somatostatin on the secretion of thyrotropin and prolactin. Endocrinology 95, 968-971.

Vassef, A. (1987). Conserved sequences near the early transcription start sites of vaccinia virus. Nucleic Acids Research 15, 1427-1443. 
Vigh-Teichmann, I., Vigh, B., Korf, H. W. \& Oksche, A. (1983). CSF-contacting and other somatostatinimmunoreactive neurons in the brain of Anguilla anguilla, Phoximus phoximus and Salmo gairdneri (Teleostei). Cell and Tissue Research 233, 319-334.

Weil, C., Crim, L. W., Wilson, C. E. \& Cauty, C. (1992). Evidence of GnRH receptors in cultured pituitary cells of the winter flounder (Pseudopleuronectes americanus W.). General and Comparative Endocrinology 85, 156-164.

Weil, C., Hansen, P., Hyan, D., Le Gac, F., Breton, B. \& Crim, L. N. (1986). Use of pituitary cells in primary culture to study the regulation of gonadotropin hormone (GtH) secretion in rainbow trout: setting up and validating the system as assessed by its responsiveness to mammalian and salmon ganodotropin releasing hormone. General and Comparative Endocrinology 62, 202-209.
White, B. A., Lufrin, T., Preston, G. H. \& Bancroft, C. (1986). RNA dot and blot hybridization: selected procedures for endocrine and neuroendocrine studies. Methods in Enzymology 124, 269-278.

Wigham, T. \& Batten, T. F. C. (1984). In vitro effects of prolactin and growth hormone release by the pituitary of Poecilia latipimna. General and Comparative Endocrinology $55,444-449$.

Wigham, T., Nishioka, R. S. \& Bern, H. A. (1977). Factors affecting in vitro activity of prolactin cells in the euryhaline teleost, Sarotherodon mossambicus (Tilapia mossambica). General and Comparative Endocrinology 32, 120-131.

Yada, T., Urano, A. \& Hirano, 'T. (1991). Growth hormone and prolactin gene expression and release in the pituitary of rainbow trout in serum-free culture. Endocrinology 129 , 1183-1192. 